\title{
Cervical spondylodiscitis as a rare presentation of neck pain in a systemically well patient
}

\author{
William Chaundy, ${ }^{1,2}$ Jeffrey Lee, ${ }^{3}$ Jeremy Berger ${ }^{4}$
}

${ }^{1}$ Department of Acute Medicine, Barnet Hospital, London, UK

${ }^{2}$ Department of General Surgery, Basildon Hospital, Basildon, UK

${ }^{3}$ Department of Rheumatology and General Medicine, Barnet Hospital, London, UK

${ }^{4}$ Department of Radiology, Barnet Hospital, London, UK

\section{Correspondence to}

William Chaundy, w. chaundy1988@gmail.com

Accepted 27 November 2014
CrossMark

$$
\begin{aligned}
& \text { To cite: Chaundy W, Lee J, } \\
& \text { Berger J. BMJ Case Rep } \\
& \text { Published online: [please } \\
& \text { include Day Month Year] } \\
& \text { doi:10.1136/bcr-2014- } \\
& 206239
\end{aligned}
$$

\section{DESCRIPTION}

We present a case of a 73-year-old woman with gradual onset severe neck pain for 5 days, radiating to head and shoulders. Her medical history included osteoarthritis and cervical spondylosis. On examination she was non-feverish, systemically well with no neurological signs. Movements were limited by pain and no focal spinal tenderness was found. A C reactive protein of 263 and erythrocyte sedimentation rate of 83 in the absence of a clear alternative infective source prompted further investigation.

MRI of the cervical spine in the short T1 inversion recovery sequence demonstrated a subtle increase in signal in the $\mathrm{C} 5-\mathrm{C} 6$ disc with prevertebral and postvertebral oedema (figure 1). The T1 sequence is highly suspicious of an early discitis, with disruption of the usually smooth end plate of C5 (figure 2). A repeat MRI with gadolinium highlights more clearly the high signal in the anterior disc and surrounding soft tissues (figure 3).

Spondylodiscitis can have serious consequences from local destruction, neurological involvement or as a source of sepsis. Patients can present with nonspecific pain only with fever in as few as $14 \%$ of cases, ${ }^{1}$ and positive blood culture in as few as $39 \% .^{2}$ MRI with gadolinium enhancement significantly improves sensitivity enhancing the disc, vertebral surfaces and surrounding soft tissue giving

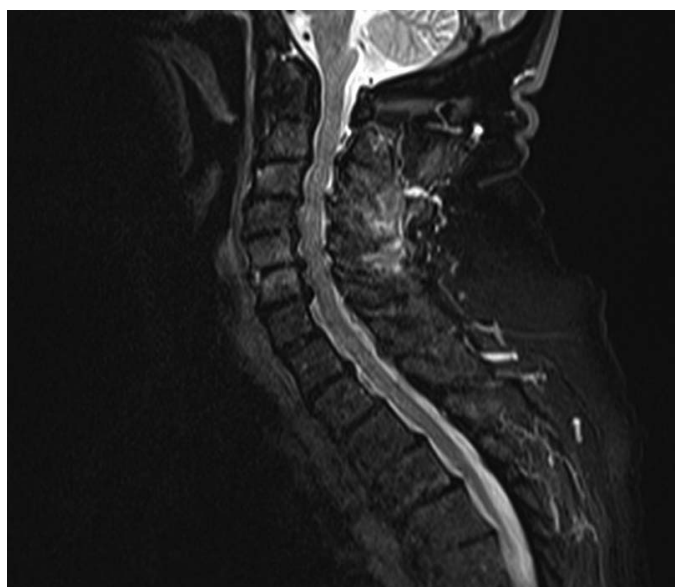

Figure $1 \mathrm{MRI}$ sagittal short T1 inversion recovery sequence. Note high signal anteriorly within the C5/6 disc, within the adjacent $\mathrm{C} 5$ and $\mathrm{C} 6$ vertebral bodies. High signal is also present within the prevertebral soft tissues and surroundings the posterior elements at $\mathrm{C5}$ and C6, consistent with oedema.

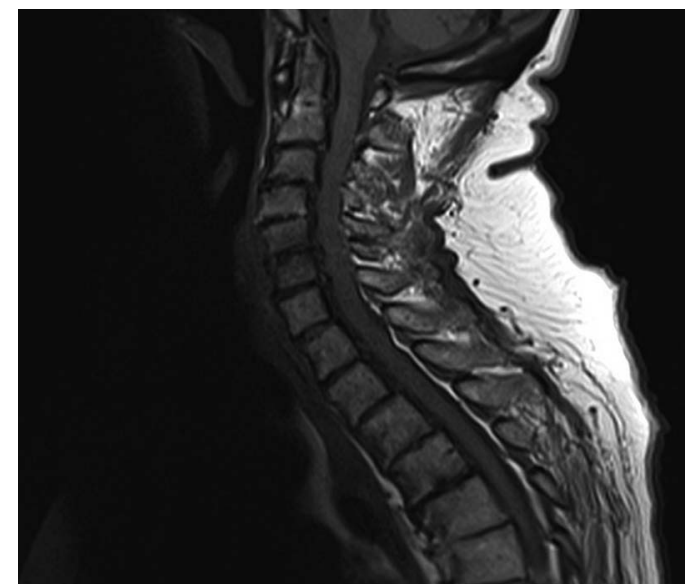

Figure 2 Sagittal T1 precontrast sequence. There is ill definition and erosion of the superior end plate of the $\mathrm{C} 5$ vertebral body, evidence of discitis.

better distinction between degenerative changes and infective lesions. ${ }^{3}$ There are numerous treatment regimens but in the absence of positive cultures empirical intravenous antibiotics targeting Staphylococcus aureus were used. A 2-week course of flucloxacillin with teicoplanin for 4 weeks as an outpatient showed resolution both clinically and biochemically.

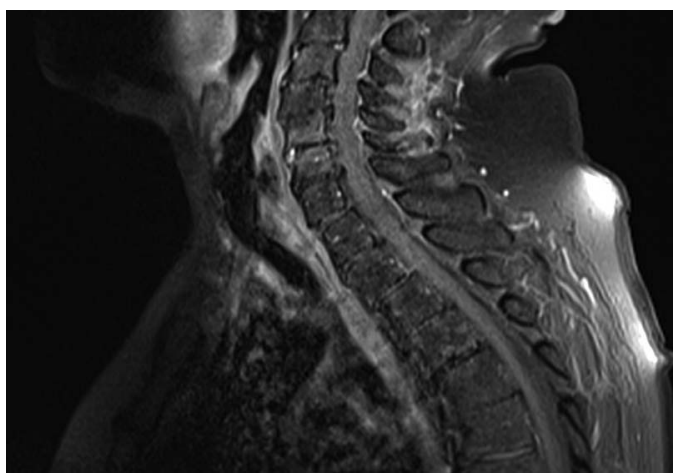

Figure 3 Sagittal T1 fat saturated post-intravenous gadolinium. There is enhancement (high signal) within the C5/6 disc anteriorly and within the adjacent $\mathrm{C} 5$ and C6 vertebrae. There is also enhancement within the thickened prevertebral soft tissues and within the soft tissues adjacent to the cervical posterior elements. 


\section{Learning points}

- Cervical spondylodiscitis can be a rare cause of severe neck pain in the systemically well patient and can present in the absence of infective signs.

- MRI with gadolinium contrast maybe required to make a definitive diagnosis and to distinguish between infective and spondylotic features.

- Treatment requires a prolonged course of intravenous antibiotics which should begin empirically and be adjusted if a specific pathogen can be identified.
Contributors $J L$ supplied case information. WC wrote the article and JL edited it; and images and image captions were by JB.

Competing interests None.

Patient consent Obtained.

Provenance and peer review Not commissioned; externally peer reviewed.

\section{REFERENCES}

1 Wirtz DC, Genius I, Wildberger JE, et al. Diagnostic and therapeutic management of lumbar and thoracic spondylodiscitis-an evaluation of 59 cases. Arch Orthop Trauma Surg 2000;120:245-51.

2 Beronius M, Bergman B, Andersson R. Vertebral osteomyelitis in Göteborg, Sweden: a retrospective study of patients during 1990-95. Scand J Infect Dis 2001;33:527-32.

3 Dagirmanjian A, Schils J, McHenry M, et al. MR imaging of vertebral osteomyelitis revisited. AJR Am J Roentgenol 1996;167:1539-43.

Copyright 2014 BMJ Publishing Group. All rights reserved. For permission to reuse any of this content visit http://group.bmj.com/group/rights-licensing/permissions.

BMJ Case Report Fellows may re-use this article for personal use and teaching without any further permission.

Become a Fellow of BMJ Case Reports today and you can:

- Submit as many cases as you like

- Enjoy fast sympathetic peer review and rapid publication of accepted articles

- Access all the published articles

- Re-use any of the published material for personal use and teaching without further permission

For information on Institutional Fellowships contact consortiasales@bmjgroup.com

Visit casereports.bmj.com for more articles like this and to become a Fellow 